\title{
La noción de reparación en naturaleza en el sistema continental de matriz francesa
}

DOI: http://dx.doi.org/10.15425/2017.512

\section{Resumen}

La reparación integral puede cumplirse en naturaleza o por equivalente pecuniario. Esa afirmación es un lugar común. Pero al menos uno de sus elementos dista mucho de estar definido: no existe una noción técnica de la reparación en naturaleza. Este artículo pretende elaborarla, con base en un análisis sobre el principio de reparación integral y de otras figuras afines con las que dicha forma de reparación suele ser confundida.

\section{Palabras clave}

Responsabilidad, reparación en naturaleza, compensación, daño y perjuicio.

Doctor en derecho de las universidades Panthéon-Sorbonne (París 1) y Externado de Colombia, magíster en responsabilidad civil del Externado, especialista en derecho comercial de la Pontificia Universidad Javeriana, abogado de la Universidad de La Sabana. Profesor de derecho civil y comercial en la Universidad Militar Nueva Granada (sede Campus), donde también es jefe del Área de Derecho Privado. Correo electrónico: diego.garcia@unimilitar.edu.co. Orcid: 0000-0002-2284-9342. 


\title{
The concept of specific reparation in the French civil law system
}

\begin{abstract}
Full compensation can be achieved by means of damages and specific reparation. This statement is a cliché. However, at least one of its elements is extremely far for being defined. There is not a technical concept of specific reparation. The objective of this article is to build that concept based on an analysis of full reparation principle and related matters with which it is often confused.
\end{abstract}

\section{Keywords}

Liability, specific reparation, compensation, damage, harm. 


\section{Introducción}

Varios autores afirman que la reparación de perjuicios puede ser pecuniaria o en naturaleza ${ }^{1}$. La jurisprudencia colombiana también lo afirma ${ }^{2}$. Esta última la aplica en casos concretos, y aquella la ejemplifica con base en esos mismos casos.

Pero la uniformidad no se traduce en precisión ${ }^{3}$. La explicación académica de una figura y su aplicación judicial deben ajustarse a la técnica, lo que supone dar un paso antes de explicarla y aplicarla: hay que definirla técnicamente. Eso no ha ocurrido con la reparación en naturaleza, salvo algunos casos puntuales ${ }^{4}$. La doctrina, en Francia y Colombia, la define como una forma de reparación no pecuniaria ${ }^{5}$, y la jurisprudencia colombiana la aplica como medio de salvaguarda del principio de reparación integral ${ }^{6}$, en aquellos casos en los que considera que la reparación económica es insuficiente.

Ambos abordajes son errados. El de la doctrina, porque define la reparación en naturaleza a partir de lo que ella no es; el de la jurisprudencia, porque utiliza la figura para asegurar la aplicación de otra figura, pero sin desentrañar los elementos

Philippe Brun, Responsabilité civile extracontractuelle (París: Lexis Nexis, 2014), 403-405; Bertrand Fages, Droit des obligations (París: LGDJ, 2018), 387; María Cecilia M'Causland, Equidad judicial y responsabilidad extracontractual (Bogotá: Universidad Externado de Colombia, 2019), 342; Fernando Hinestrosa, "La responsabilidad civil ", en Escritos varios (Bogotá: Universidad Externado de Colombia y Umaña Trujillo Impresores, 1983), 690, aunque este autor lo hace con una terminología distinta, oponiendo "el restablecimiento" y "la restitución" a "los sucedáneos"; Andrea Pinna, La mesure du préjudice contractuel (París: LGDJ, 2007), 1.

2 Colombia, Corte Suprema de Justicia, Sala de Casación Civil, sentencia del 24 de mayo de 1999, exp. 5244. En esta sentencia la Corte se refirió a la reparación en naturaleza como "reparación directa", en oposición a las reparaciones dinerarias, que denominó "indirectas o equivalentes".

Además, el argumento que se basa simplemente en la communis opinio constituye una falacia ad populum: esta "consiste en afirmar que algo es cierto (o que no lo es) porque constituye la opinión mayoritaria [...] basar la certeza (o falsedad) de algo en que todo el mundo así lo afirma o niega": María Camila Correa Flórez, "Taxonomía de las falacias argumentativas", en Una mirada a la argumentación jurídica, Renata Amaya y Nicolás Parra (coords.) (Bogotá: Ediciones Uniandes, 2019), 104. Brunehilde Barry, La réparation en nature (París: LGDJ y Presses de l'Université Toulouse 1 Capitole, 2016), passim.

Arturo Solarte Rodríguez, "La reparación in natura del daño", Revista Universitas, v. 54, n. 109 (2005), 206 a 209; M'Causland, "Equidad judicial”, 342; Geneviève Viney, Patrice Jourdain, Suzanne Carval, Les effets de la responsabilité (París: LGDJ, 2011) § 14-1; Eugène Gaudemet, Théorie générale des obligations (París: Dalloz, reimpresión de la primera edición, 2004), 323; Louis Josserand, De l'esprit des droits et de leur relativité. Théorie dit de l'abus des droits (Paris: reimpresión de la primera edición, Dalloz, 2006), §§ 326 y siguientes. 
esenciales de la primera. Esto equivale a sobreentender un concepto jurídico, lo que resulta inaceptable en las decisiones judiciales.

El objetivo de este artículo es elaborar una noción de reparación en naturaleza. Para alcanzarlo se analizará el principio que subyace tras la reparación en naturaleza, o sea el de la reparación integral. Ese análisis se centrará en precisar los factores que conforman la integralidad de la reparación. Ello es pertinente porque la ley colombiana, en normas de orden público ${ }^{7}$, indica que la reparación debe ser integral, pero no explica los conceptos de reparación ni de integralidad.

Doctrina y jurisprudencia sí lo han hecho, pero en términos que juzgamos incompletos. Aquella afirma que la reparación integral consiste en reparar todo el daño, pero nada más que el daño ${ }^{8}$. De ello infiere que la reparación debe concordar cuantitativamente con el daño, y que, por lo tanto, ella no puede enriquecer ni empobrecer a la víctima.

Todo eso es correcto, pero deja sin resolver la incógnita sobre lo que debemos entender por reparación, así como las formas que esta puede revestir y los factores que componen su integralidad. De ahí la importancia de precisar esos conceptos. ¿Qué es reparar? ¿Qué debe contener una reparación para ser integral? ¿Reparar es lo mismo que indemnizar? ¿Los daños patrimoniales realmente pueden repararse? ¿La reparación en naturaleza no puede ser dineraria? ¿Las prestaciones simbólicas reparan?

A esas preguntas pretendemos darles respuesta. Para ello acudiremos el método dogmático" cuyo propósito es "teorizar; es decir, agrupar y unir de forma ordenada un conjunto de dispositivos legales sobre un referente común"10. Ese método nos permitirá desentrañar el contenido de conceptos como los referidos en el párrafo anterior, en el entendido de que ellos surgen de reglas positivas en sentido amplio, tanto legales como jurisprudenciales. La investigación, por consiguiente,

Art. 283 del Código General de Proceso y art. 16 de la Ley 446 de 1998. debe ser integral, y aclara que ella debe propender por dejar a la víctima en el estado en el que estaría si el daño no hubiese ocurrido nunca: Arturo Solarte Rodríguez, "Principio de la reparación integral del daño en el derecho contemporáneo", en La responsabilidad civil en el siglo XXI (Medellín: Biblioteca Jurídica Diké y Pontificia Universidad Javeriana, 2009), 121 a 155.

9 "A partir de la formulación de un problema jurídico el investigador comienza a hacer la selección de un conjunto normativo que, por relación de unidad, regula por vía fáctica o conceptual el problema al que alude": Óscar Agudelo-Giraldo, "Los calificativos del derecho en las formas de investigación jurídica”, en Óscar Agudelo-Giraldo (editor), La pregunta por el método: derecho y metodología de la investigación (Bogotá: Universidad Católica de Colombia, 2018), 31.

10 Manuel Sánchez Zorrilla, "La metodología de la investigación jurídica: características peculiares y pautas generales para investigar en derecho", Revista Telemática de Filosofía del Derecho, n. ${ }^{\circ} 14$ (2011). http://www.rtfd.es/numero14/11-14.pdf 
es del todo teórica, pues se basa en el análisis disciplinar de "nociones ideales, [de] formas lingüísticas elaboradas por el hombre, [de] constructos racionales y simbólicos que la ciencia ha elaborado $[. . .]^{\prime 11}$.

El estudio no está circunscrito al derecho de un país en especial. Se trata de elaborar una teoría y de sacar conclusiones funcionales para el sistema continental de origen francés, entendiendo por tal al derecho civil de los países que se sirvieron en mayor medida del Código de Napoleón ${ }^{12}$ que de la Pandactística y del Código Civil alemán ${ }^{13}$. Por tal razón, el trabajo se fundamenta principalmente con las fuentes doctrinales, legales y jurisprudenciales ${ }^{14}$ de Francia y Colombia ${ }^{15}$.

El plan de redacción se estructura en dos partes. En la primera analizaremos los elementos que determinan la integralidad de la reparación (I). Ello nos permitirá formular la noción que buscamos. Esta será puesta a prueba en la segunda parte, por medio de una confrontación entre la reparación en naturaleza y las figuras con las que suele ser confundida (II).

\section{La integralidad de la reparación}

Para formular la noción hay que situarse en el ámbito en el que se pretende su aplicación. Ese ámbito, en este trabajo, es el de la responsabilidad por daños. Esto implica, por una parte, la exclusión de otros mecanismos de reparación ${ }^{16} \mathrm{y}$, por otra parte, la inclusión de los dos sistemas de responsabilidad patrimonia ${ }^{17}$ : el privado y

11 Carlos Villabella-Armengol, "Los métodos en la investigación jurídica". https://archivos.juridicas. unam.mx/www/bjv/libros/8/3983/46.pdf

12 Como Colombia, Chile, Ecuador, España y la provincia canadiense de Quebec.

13 Como Italia (1942), Austria y Suiza.

14 Cabe resaltar la influencia que siempre ha tenido el derecho francés en nuestra jurisprudencia. Ello se hace evidente, por ejemplo, en la construcción que ella ha forjado en temas como la responsabilidad por actividades peligrosas, la clasificación de las obligaciones en de medios y de resultado, el abuso del derecho, el enriquecimiento sin causa y la configuración de la falla del servicio.

15 No se trata de un estudio de derecho comparado. Simplemente se recogerán las teorías y planteamientos franceses, en el entendido de su pertinencia para ser aplicadas en Colombia, e incluso en cualquier país del sistema continental de matriz francesa.

16 Como la seguridad social, los fondos de indemnización y los seguros privados.

17 “[...] el fenómeno de la reparación de un daño cubre todos los campos del derecho [...] la responsabilidad llamada del Estado [...] en su esencia versa sobre el mismo problema jurídico: la naturaleza de la obligación de reparar un daño antijurídico imputable": Obdulio Velásquez Posada, Responsabilidad civil extracontractual (Bogotá: Temis, 2013), 9. 
el estatal. Los planteamientos que hagamos y las conclusiones a las que lleguemos tendrán la misma validez en los dos ámbitos.

Ese marco de referencia obliga a precisar conceptos previos e indispensables. Lo son para derivar de ellos la noción bajo análisis. Por ello se partirá de la premisa de que el juez en un proceso de responsabilidad tendrá que analizar la presencia o ausencia de las condiciones de la responsabilidad: daño, hecho generador y nexo causal. En efecto, la condena y la absolución suponen la constatación o el descarte de esas condiciones, en lo que podría denominarse el juicio de responsabilidad. El alcance del artículo nos impide analizar el hecho generador y el nexo causal, pero nos obliga a analizar el daño como objeto de la reparación ( $A$ ), y a la reparación como factor de la integralidad (B).

\section{A) El daño como objeto de la reparación}

Según la communis opinio, la responsabilidad civil es "la obligación de reparar los daños causados a otro". Con esas palabras textuales la definen los profesores franceses Fages ${ }^{18}$ y Brun ${ }^{19}$. Le Tourneau la define como "La obligación de responder ante la justicia por un daño, y de reparar sus consecuencias indemnizando a la víctima ${ }^{20 "}$. En Colombia, Henao la define con base en su función: "El objetivo de esta última [de la responsabilidad] es la reparación de daños" ${ }^{21}$. M'Causland lo hace abarcando todos los elementos estructurales de la responsabilidad en su definición: "La responsabilidad puede definirse como la obligación de reparar el daño causado a una persona, que corresponde a otra persona a quien dicho daño resulta imputable por existir fundamento jurídico para ello"22. En síntesis, la responsabilidad civil es la obligación de reparar los daños injustificados causados a otra persona.

Con base en lo anterior, puede inferirse que el objeto de la responsabilidad es reparar y que el objeto reparable es el daño. Reparación y daño son entonces sus protagonistas. $Y$ eso impone adentrarse en las minucias técnicas de lo que cada una de esas cosas es, para comprender, a partir de ahí, qué es lo que por medio de la responsabilidad se repara. 
La ley no define el verbo reparar. En el lenguaje jurídico se utiliza indistintamente con otros vocablos, como resarcir, compensar o indemnizar. La falta de una definición legal, y la sinonimia con la que se trata el término por los juristas, torna procedente indagar por el significado que la autoridad lingüística de la lengua española le atribuye. Ello se sustenta en uno de los criterios de interpretación de la ley, que fija el artículo 28 del Código Civil colombiano. Según él, las palabras de la ley deben entenderse en su sentido natural y obvio.

Pues bien, el Diccionario de la lengua española define reparar como "Enmendar, corregir o remediar, desagraviar, satisfacer al ofendido". El verbo resarcir es definido como "Indemnizar, reparar, compensar un daño, perjuicio o agravio", y el verbo indemnizar es definido como "Resarcir de un daño o perjuicio [...]".

Puede verse que la semántica asemeja los conceptos, y que, entonces, la asimilación de los juristas es válida. También puede verse que lo propio de la reparación o de cualquiera de sus sinónimos es enmendar, arreglar, corregir, remediar una situación nociva. Eso concuerda con la definición que la Corte de Casación francesa ha aceptado invariablemente desde 1954, según la cual la reparación consiste en "situar a la víctima en la situación en la que se encontraría si el acto dañoso no se hubiera producido" ${ }^{23}$.

Ahora bien, dentro de la asimilación que hacen los juristas y la autoridad lingüística, convendría resaltar un detalle: al definir el verbo indemnizar, el Diccionario de la lengua española lo hace diciendo que consiste en "resarcir un daño o un perjuicio, generalmente mediante una compensación económica". Eso marca una diferencia. Aunque la indemnidad no se alcanza solo con el dinero, las indemnizaciones sí se pagan siempre en dinero.

Aunque el diccionario matiza con el adverbio generalmente, es evidente que las indemnizaciones siempre se pagan en dinero, tanto las que provienen de la responsabilidad como las que provienen de otros mecanismos, como los fondos de indemnización, el derecho laboral o la seguridad social. Tanto es así que la propia Real Academia Española, en el Diccionario panhispánico del español jurídico ${ }^{24}$, publicado en el 2020, elimina el matiz y define la indemnización, en todas sus acepciones jurídicas, como "compensación económica destinada a reparar [...]"25. dique, 1955, II, 8765 .

El carácter panhispánico de este diccionario implica que las acepciones incluidas en él corresponden de manera uniforme a todos los países de habla hispana, lo que significa que el término de marras, indemnización, es reconocido como compensación económica en el ámbito jurídico de todos esos países. 
El soft law internacional también lo reconoce: los Principios de Derecho Europeo de la Responsabilidad dicen que "la indemnización es un pago en dinero para compensar a la víctima"26. La Corte Interamericana de Derechos Humanos, en el marco de la responsabilidad internacional del Estado, ha establecido lo mismo ${ }^{27}$. La ley de víctimas del conflicto armado, en Colombia, hace lo propio ${ }^{28}$.

Por consiguiente, la reparación es una figura remedial, restaurativa, correctora; es un medio para arreglar algo que está descompuesto o estropeado, mientras que la indemnización es un mecanismo compensatorio y paliativo, que funge como lenitivo, y no como restaurador del estado de cosas anterior al daño.

El derecho, en todo caso, ordena indistintamente reparar o indemnizar, acogiendo una sinonimia válida pero matizable. En la siguiente sección se presentará el efecto práctico de esa matización conceptual. En esta se pretende, por una parte, delimitar el concepto de reparación y, por otra parte, definir el daño en cuanto objeto reparable. Para lograr esas metas se acudirá respectivamente a la interpretación exegética y a la revisión doctrinal del concepto de daño.

El primer paso en un proceso de responsabilidad es confirmar o descartar el daño ${ }^{29}$. La lógica así lo impone. En caso de haberlo, el juicio debe avanzar hacia la determinación de su carácter resarcible. Dicha determinación resultaría de la comprobación de las otras dos condiciones de la responsabilidad. En cambio, si de entrada se comprueba su inexistencia, se tornaría impertinente la averiguación de más cosas.

¿Pero qué es daño? La doctrina se ha ocupado de definirlo. Para Viney, Jourdain y Carval, el daño es "La lesión de un interés"30. Para Brun es "La afectación de la integridad de una persona o de una cosa" ${ }^{31}$. Cadiet opina que "Él se define

Artículo 10.101.

Véase, por ejemplo, Suárez Rosero contra Ecuador: sentencia del 29 de mayo de 1999, https:// www.corteidh.or.cr/tablas/fichas/suarezrosero.pdf; Acevedo Jaramillo y otros contra Perú: sentencia del 7 de febrero del 2006, https://www.corteidh.or.cr/docs/casos/articulos/seriec_144_esp. pdf; en igual sentido, Pérez León-Acevedo afirma que "la relación entre reparación y conceptos tales como restitución, indemnización y satisfacción es de género a especie”: Las reparaciones en el derecho internacional de los derechos humanos, derecho internacional humanitario y el derecho penal internacional, https://www.corteidh.or.cr/tablas/R22048.pdf

8 Ley 1448 del 2011, art. 25, inciso segundo: "La reparación comprende las medidas de restitución, indemnización, rehabilitación, satisfacción y garantías de no repetición...”. Evidentemente, para esta ley, entre reparación e indemnización hay una relación de género a especie, pues afirma que "la reparación comprende", entre otros factores, la indemnización.

En igual sentido, Mariano Yzquierdo-Tolsada, Responsabilidad civil extracontractual (Madrid: Dykinson, 2019), 159.

Viney, Jourdain, Carval, "Les effets”, 25.

Brun, Responsabilité civile extracontractuelle, 118. 
como lesión"32. Entre los colombianos, Tamayo lo define como "Menoscabo a las facultades jurídicas que tiene una persona para disfrutar de un bien patrimonial o extrapatrimonial [...]"33.

Estas definiciones son acertadas. Se justan a la técnica disciplinar y concuerdan con el objeto de la responsabilidad. Todas ellas se centran con acierto en el concepto de lesión. No obstante, les falta incluir los conceptos de derecho e interés: la lesión debe recaer sobre algo. Ese algo es un derecho, entendido como prerrogativa dotada de acción, o un interés ${ }^{34}$, entendido como situación favorable, pero carente de acción. Puede lesionarse un derecho, como el de propiedad, o el de crédito o uno fundamental, pero también puede menoscabarse una situación favorable pero carente de acción, como les ocurre a los hijos de crianza con la muerte de sus padres putativos.

Así pues, el daño sería la lesión injustificada ${ }^{35}$ de un derecho o interés. Como complemento necesario de esta definición, habría que incorporar los elementos que componen el objeto definido. No se trata de descomponer la definición en sus partes, sino de comprender que, a partir de la definición dada, se debe concebir al daño como portador de dos facetas distintas: como portador de un elemento objetivo y como portador de un elemento subjetivo.

El elemento objetivo del daño es la lesión propiamente dicha ${ }^{36}$. Es la afectación pura y simple, el hecho escueto del golpe al derecho o al interés. La objetividad se traduce en la materialidad: la lesión es constatable en el mundo de lo fáctico y es igual para cualquier víctima.

El elemento subjetivo, en cambio, corresponde a las repercusiones puntuales que produce para cada individuo en particular la lesión sufrida ${ }^{37}$. La subjetividad se deriva de las circunstancias especiales de cada víctima. No operan criterios de

Loïc Cadiet, Le préjudice d'agrément, tesis doctoral (mimeografiada) (Poitiers: Universidad de Poitiers, 1983), 372.

M'Causland, "Equidad judicial", 338 y 339, lo explica acertadamente al definir el daño: “... Pérdida o menoscabo [...] sufrido por un sujeto de derecho, resultante de la lesión a un derecho subjetivo o a un interés legítimo, esto es, de la lesión a un derecho provisto de acción o a un interés que, si bien carece de esta, no está prohibido por el orden jurídico".

35 La falta de justificación del daño también es esencial en la definición, porque existen daños justificados que, por ende, no son resarcibles, como la imposición de obligaciones tributarias o de multas por infracciones de tránsito. jetos que lo sufran, siempre que el detrimento sea el mismo". Álvaro Mendoza Ramírez, Obligaciones (Bogotá: Temis, 2020), 782. 
generalización ni de homogeneidad. Al contrario, cada sujeto padece efectos nocivos distintos, aunque la fuente de dichos efectos sea una lesión objetivamente comparable con la de otro sujeto que padezca la misma lesión.

Esta división del daño no es novedosa. La doctrina francesa la explica diferenciando daño y perjuicio. Para quienes en Francia la defienden, el daño es lo que en este artículo se denomina elemento objetivo, y el perjuicio es lo que en este artículo se denomina elemento subjetivo. En Italia la distinción opera bajo las rúbricas respectivas de daño-evento y daño-consecuencia. Un sector de la doctrina colombiana también la ha defendido ${ }^{38}$, y la Corte Suprema de Justicia la acogió recientemente ${ }^{39}$, usando la nomenclatura francesa.

Cabe anotar que la distinción es acertada, pero no opera entre daño y perjuicio, como lo dicen tanto la doctrina francesa y colombiana como la Corte Suprema de Justicia. Una distinción no puede hacerse entre sinónimos. Menos aún si se tiene en cuenta que la ley no los define, pero cuando los usa lo hace indistintamente. Por ello sugerimos discernir un elemento objetivo de un elemento subjetivo del daño. Evidentemente, tal discernimiento corresponde al que se hace sobre el daño y el perjuicio, pero resulta más preciso porque no ignora la sinonimia "natural y obvia" que la semántica y la ley le adjudican a esos dos términos ${ }^{40}$.

La distinción tiene detractores. Algunos afirman que, a pesar de su lógica intrínseca, ella no debe aplicarse porque los códigos no lo hacen. En síntesis, ellos usan tácitamente el argumento de que donde la ley no distingue, no debe hacerlo el intérprete ${ }^{41}$. Otros la consideran "inútilmente compleja" en atención al origen etimológico de los dos términos: dicho origen no permite atribuirles significación dispar ${ }^{42}$. Tamayo considera que la distinción es absurda porque implica comprender que "hay bienes jurídicos cuya protección no está al alcance del orden jurídico civil" ${ }^{33}$, argumento que remata diciendo que "es innecesario insistir en la diferencia

Pedro Zapata García, Fundamentos y límites de la responsabilidad del Estado (Bogotá: Universidad Externado de Colombia, 2019), 177 a 179; María Cecilia M'Causland, Tipología y reparación del daño inmaterial en Colombia (Bogotá: Universidad Externado de Colombia, 2015), 14; en contra, Javier Tamayo Jaramillo, Tratado de responsabilidad civil (Bogotá: Legis, 2007), 329 y 333.

Colombia, Corte Suprema de Justicia, Sala de Casación Civil, sentencia del 3 de abril del 2019, rad. 11001-31-03-015-2010-00268-01, exp. SC-3653-2019.

40 Cabe aclarar que la distinción no tiene ninguna relación con la división de los daños y perjuicios en patrimoniales y extrapatrimoniales. Tanto la lesión al derecho como sus consecuencias pueden recaer sobre derechos e intereses patrimoniales y extrapatrimoniales, y una lesión patrimonial puede producir efectos extrapatrimoniales y viceversa.

41 Viney, Jourdain, Carval, "Les effets", 3 y 4.

42 Muriel Fabre-Magnan, Droit des obligations, t. II (París: Presses Universitaires de France, 2013), 176.

43 Tamayo, Tratado de responsabilidad civil, 329. 
entre daño y perjuicio, bastando [sic] simplemente entender que toda disminución de beneficios alrededor de una cosa o persona constituye un daño o perjuicio"44.

Dichas críticas son rebatibles. Sobre el argumento de que no se debe distinguir donde la ley no lo hace, habría que decir que las distinciones no tienen que formularse expresamente. En efecto, los textos legales no distinguen los términos de marras, en el sentido de dedicar artículos o incisos a elaborar la distinción. Pero el derecho es un sistema, y de su interpretación armónica sí que se infiere la distinción.

Por ejemplo, la ley determina qué elementos componen la indemnización ${ }^{45}$ : el daño emergente y el lucro cesante ${ }^{46}$. Es evidente que uno y otro son consecuencias de la lesión al derecho, pues si hay lesión, pero no hay alguna de esas dos consecuencias, entonces no habría responsabilidad.

Más aún: el artículo 1614 del Código Civil define el daño emergente y el lucro cesante a partir de una situación que pone de relieve la distinción, pues dice que aquellos daños deben resultar "a consecuencia de no haberse cumplido la obligación". La norma, pues, reconoce tácitamente la diferencia entre la lesión al derecho de crédito y los efectos que esta desata. Por consiguiente, la premisa de que "la ley no distingue" es falsa en este caso.

En cuanto al argumento etimológico, este resulta insuficiente. Una cosa es el origen de un término y otra cosa es su significado actual, tanto técnico, cuando lo haya, como semántico. Por ejemplo, la palabra ojalá tiene su origen etimológico en la expresión árabe law šá lláh", que significa "si dios quiere". En español ese término simplemente "denota [el] vivo deseo de que suceda algo" 48 , sin incluir el componente religioso. Así pues, el origen etimológico de los términos no implica la vigencia contemporánea de dicho origen.

Los argumentos de Tamayo también son objetables. El primero, porque su conclusión no se deduce de las premisas que lo sustentan. En otros términos, el

Tamayo, Tratado de responsabilidad civil, 333.

Código Civil colombiano, art. 1613: “La indemnización de perjuicios comprende el daño emergente y lucro cesante...".

Código Civil, art. 1614: “Entiéndese por daño emergente el perjuicio o la pérdida que proviene de no haberse cumplido la obligación o de haberse cumplido imperfectamente, o de haberse retardado su cumplimiento; y por lucro cesante, la ganancia o provecho que deja de reportarse a consecuencia de no haberse cumplido la obligación, o cumplido imperfectamente, o retardado su cumplimiento".

Véase https://dle.rae.es/?w=ojal\%C3\%A1

Véase https://dle.rae.es/?w=ojal\%C3\%A1 
autor incurre en una falacia del tipo non sequitur ${ }^{49}$. Él afirma que la distinción conduce a considerar que "hay bienes jurídicos cuya protección no está al alcance del orden jurídico civil". Esos bienes - según él, sin protección- serían los derechos o intereses lesionados, porque la distinción entiende que el objeto reparable son las consecuencias de la lesión, y no esta. En síntesis, aceptar la distinción, para Tamayo, equivale a aceptar que solo las consecuencias de la lesión son protegibles por el derecho.

Ese razonamiento es cuestionable. Una cosa es que esos bienes no tengan protección, como lo afirma Tamayo, y otra es que sean protegibles bajo mecanismos distintos a la responsabilidad. Lo primero es falso. Lo segundo es cierto. El hecho de que la consecuencia ligada a la lesión no sea la reparación no significa que la lesión quede sin protección.

Piénsese en la sentencia civil en la que se reconoció por primera vez la responsabilidad por violación de los derechos fundamentales: esta le atribuye consecuencias a la sola lesión de dichos derechos ${ }^{50}$. Claramente hay una consecuencia, un mecanismo de protección, aunque no concuerda con los conceptos de reparación y de responsabilidad, a pesar de las afirmaciones de la Corte en sentido contrario.

El segundo argumento de Tamayo, según el cual basta con "entender que toda disminución de beneficios alrededor de una cosa o persona constituye un daño o perjuicio", constituye una petición de principio ${ }^{51}$. El autor descarta la distinción afirmando simplemente que los dos términos significan lo mismo. Es decir, no hay que distinguir daño de perjuicio porque son la misma cosa. Eso es dar por cierto lo que se pretende comprobar.

Luego de haber presentado la distinción entre el elemento objetivo y subjetivo del daño, y de haber presentado los argumentos a favor y en contra de su validez, se procede ahora a explicar los efectos de su implementación. A pesar de no ser novedosa, y a pesar de no ser uniformemente aceptada, la distinción tiene efectos prácticos ${ }^{52}$ que permiten entender de manera más adecuada la teoría de la

49 La falacia non sequitur consiste en "extraer una conclusión que 'no se sigue'. Por ejemplo, una conclusión que no es una inferencia razonable de la prueba". Antony Weston, Las claves de la argumentación, Jorge Malem-Seña (trad.) (Bogotá: Ariel, 2005), 131.

50 Colombia, Corte Suprema de Justicia, Sala de Casación Civil, 5 de agosto del 2014, rad. 110013103 003200300660 01: "En cuanto al menoscabo del derecho al buen nombre, hay que reconocer que el daño se configura cuando se demuestra la violación de ese bien jurídico, sin que se requiera la presencia de ninguna otra consecuencia" (énfasis añadido).

51 La petición de principio es una falacia argumentativa que "se configura cuando se asume la verdad de lo que se intenta probar, durante el intento de probarlo”. Correa-Flórez, "Taxonomía de las falacias”, 106.

52 Sobre dichos efectos: Diego García, La oficialización de la pena privada en Colombia (Bogotá: Universidad Externado de Colombia, 2018), 177 a 180. 
reparación de daños ${ }^{53}$. Para los efectos de este artículo, la distinción entre daño objetivo y subjetivo, o entre elemento objetivo y subjetivo del daño ${ }^{54}$, sirve para delimitar el alcance de la reparación: aquella nos indica el objeto material sobre el que recae la reparación.

\section{B) La reparación en naturaleza como elemento de la integralidad}

En la sección anterior se hizo un ejercicio de conceptualización. Allí se presentaron los elementos esenciales del daño y de la reparación. Con base en esos elementos esenciales, se pueden hacer las siguientes observaciones: en primer lugar, la reparación solo puede recaer en el elemento objetivo del daño. En segundo lugar, la reparación solo puede efectuarse de forma específica, es decir, sin erogaciones dinerarias. En tercer lugar, la indemnización solo es aplicable al elemento subjetivo del daño. A continuación, se explica cada una de las observaciones anteriores.

La reparabilidad se predica del elemento objetivo del daño. En efecto, si la reparación es remedial, correctora, restaurativa, entonces ella solo es aplicable a la lesión del derecho o del interés, pues solo esta es susceptible de eliminarse del mundo fáctico ${ }^{55}$. Piénsese en el despido discriminatorio de un trabajador: este puede subsanarse totalmente mediante el reintegro, en cuyo caso la víctima quedaría restablecida en su statu quo ante.

Del elemento subjetivo no puede decirse lo mismo. Si el trabajador se deprimió por la pérdida, o si tuvo que pagar los servicios de una agencia de empleos, a lo sumo podrá recibir una compensación económica por esos conceptos, pero es imposible restaurarlos. Ellos quedan consumados.

Esta idea fue expuesta por Brun: "No parece del todo herético sostener que el perjuicio [...] solo puede compensarse, mientras que el daño [...] a una persona, un bien o un derecho es susceptible de otras medidas: restablecimiento, en la medida de lo posible, pero también estigmatización del autor"56.

53 La distinción también repercute en los términos de prescripción de la acción de responsabilidad, en la fecha de nacimiento de la obligación de reparar, en la relación de causalidad y en los efectos jurídicos aplicables a cada uno de los elementos discernidos.

54 En adelante, se usarán indistintamente las dos formas.

55 En contra, Hans Fischer, Los daños civiles y su reparación (Madrid: Biblioteca de la Revista de Derecho Privado, 1928), 132: "No está en la mano del hombre descartar del mundo de la realidad hechos acaecidos. A lo sumo, se podrán detener sus efectos presentes y futuros, mediante ciertas providencias y precauciones, pero nunca borrar los ya ocurridos y realizados".

56 Philippe Brun, "Personnes et préjudice”, Revue Générale de Droit (2003), 196. Brun acierta con casi todo lo que dice en este fragmento, pero nos parece que se equivoca al incluir la estigmatización como forma de reparación, pues con ello confunde pena privada con reparación. Esa confusión - por cierto, muy común- se estudiará en una sección posterior de este artículo. 
Y si esta idea es válida, la conclusión necesaria es que la única forma de reparación es la que se hace en naturaleza. Esta es la que permite alcanzar el objetivo de la responsabilidad: acercar a la víctima "a la situación que, según los cálculos de la experiencia humana y las reglas de lo probable, existiría de no haber acontecido el daño"57.

Esto nos conduce a retomar la propuesta que en su día formuló el profesor Cadiet, en el sentido de que la utilidad principal de la distinción entre el elemento objetivo y subjetivo del daño radica en que ella permite reconsiderar la tipología de las formas de reparación, conocidas como reparación en naturaleza y reparación por equivalente pecuniario. La primera se daría solo con respecto a la lesión; la segunda, solo con respecto a sus repercusiones. Así expuso la propuesta el profesor francés:

En rigor, la reparación en naturaleza es restauración, restablecimiento; ella actúa sobre la lesión, sobre el lugar que recibe la afectación, sobre el daño. Es, por ejemplo, el tratamiento médico del daño corporal o la restauración biológica del daño ecológico. La reparación por equivalente no es en realidad una reparación. Es una solución por defecto; una compensación que tranquiliza las penas sin erradicar los males ${ }^{58}$.

Esta propuesta fue acogida tácitamente en Francia por los redactores del Proyecto Catala. En ese texto académico, se utiliza el término daño en las secciones dedicadas a la reparación en naturaleza, mientras que el término perjuicio lo reserva para la indemnización de perjuicios ${ }^{59}$.

La propuesta ha sido cuestionada. Leduc ${ }^{60}$ y Barry ${ }^{61}$ han formulado ejemplos de situaciones en las que, según ellos, la reparación en naturaleza opera sobre el elemento subjetivo del daño, y deja incólume la lesión al derecho. Esos ejemplos son los siguientes:

- Daño corporal seguido de una discapacidad. El responsable es condenado a cubrir los costos de reacondicionar la casa de la víctima. Eso

Fischer, "Los daños civiles", 132.

Loïc Cadiet, "Les métamorphoses du préjudice", en Les métamorphoses de la responsabilité (París: Presses Universitaires de France, 1998), 63.

Barry, “La réparation en nature", 227.

Fabrice Leduc, "Faut-il distinguer le dommage et le préjudice?: point de vue privatiste", Revue de Responsabilité Civile et Assurances (marzo del 2010) : 16.

Barry, “La réparation en nature”, 232 y 233. 
constituye una reparación en naturaleza del daño subjetivo, que no elimina el daño objetivo.

- Clientes insatisfechos de un crucero. El operador turístico les ofrece otro crucero. La lesión a su derecho no se elimina.

- Vehículo robado o destruido. El responsable provee el dinero para uno nuevo de las mismas características.

- Daño corporal seguido de sufrimiento físico. El responsable debe cubrir el costo del tratamiento y de los medicamentos. Se compensa el dolor sin borrar la lesión corporal.

Los ejemplos refuerzan la tesis que pretenden refutar. Supuestamente ilustran casos de reparación en naturaleza de daños subjetivos, que dejan intacto el daño objetivo. Sin embargo, ninguno de ellos configura un daño subjetivo. Para configurarlo tendrían que encuadrarlos en alguna de las categorías de perjuicio material o inmaterial, pero ello no ocurre. Los costos de reacondicionamiento de la casa de la víctima no son un gasto en el que ella haya incurrido; quien va a incurrir en el gasto es el responsable.

Ello confirma que no hay daño emergente. Lo mismo puede decirse de la compra del vehículo por parte del responsable, con el agregado de que en este caso sí que se restablece el derecho de propiedad que había sido vulnerado. Ocurre lo mismo con los costos del tratamiento. La víctima no ha incurrido en ellos, pero el responsable los va a cubrir precisamente para restaurar el derecho a la salud. $Y$ en el ejemplo del crucero, lo que hay es una ejecución extemporánea del contrato, no una reparación.

Por otro lado, creemos que la reparación en naturaleza debe consistir en prestaciones de hacer, de no hacer o de dar algo que no sea dinero ${ }^{62}$. Algunos autores, desde luego, piensan distinto ${ }^{63}$. De hecho, suelen presentar ejemplos como los que relacionamos arriba: pago de un tratamiento médico, adquisición o arreglo de un vehículo robado o destruido, acondicionamiento de la vivienda de la víctima; los tres por cuenta del responsable. A esas erogaciones una autora las denomina "formas de reparación por equivalente en naturaleza" ${ }^{4}$.

En contra, Hubert Groutel, "Droit français”, en La réparation intégrale en Europe (Bruselas: Larcier, 2012), 112.

Olivia Sabard, "La forme de la réparation", en La réparation intégrale en Europe (Bruselas: Larcier, 2012), 77 y 78.

Barry, “La réparation en nature”, 201. 
Parecería que esos autores consideran que lo esencial de la reparación en naturaleza no radica en ella misma, sino en la persona que debe proveerla. Lo fundamental, para ellos, no es la forma de la reparación, sino la persona obligada a realizarla. Ese raciocinio es equivocado porque desconoce el hecho de que la condena a reparar un perjuicio supone la prueba de su existencia, y esa prueba no existe en los ejemplos referidos. Si el demandado es condenado a pagar el precio de un vehículo, tiene que ser porque la víctima lo pagó para reponer el vehículo robado o destruido. Lo mismo sucede si resulta condenado a cubrir los costos de un tratamiento médico. Estos deben haber sido cubiertos por la víctima o debe al menos tenerse la certeza de que deberá cubrirlos en el futuro.

Así se indemniza el daño emergente, que, al concretarse en las erogaciones derivadas de la lesión, supone su consumación pasada o la certeza de su consumación futura. La víctima debe acreditar que incurrió o deberá incurrir en esas pérdidas. De lo contrario, no puede haber condena.

En contraste, si el demandado es condenado a comprar un vehículo que la víctima no ha comprado, o a costear un tratamiento que la víctima no ha costeado, la condena carecería de una prueba que la sustente. No habría daño emergente. Tampoco habría lucro cesante porque este consiste en ingresos perdidos, y se indemniza pagando el valor exacto del faltante ${ }^{65}$.

Tampoco hay daño inmaterial. Si lo hubiera, la indemnización se impondría con base en las metodologías adoptadas por las dos jurisdicciones que juzgan la responsabilidad: en la ordinaria, con los techos jurisprudenciales; en la contencioso-administrativa, con salarios mínimos. El responsable debe pagar la suma correspondiente, y le compete a la víctima decidir su destinación. El dinero no tiene una finalidad establecida en la sentencia.

Por lo anterior, las condenas pecuniarias en los procesos de responsabilidad deben resultar de la acreditación de pérdidas patrimoniales, o de ingresos fallidos, o de consecuencias inmateriales de las lesiones a los derechos. En otros términos, las condenas dinerarias resultan de comprobar el padecimiento de alguno de los tipos de daño reconocidos en el ordenamiento jurídico.

Es preciso decir que la indemnización del daño emergente es un reembolso de gastos o la compensación de una pérdida contable. La del lucro cesante es el pago diferido de un ingreso que, gracias al daño, no pudo recibirse a tiempo, y la de los perjuicios inmateriales es la compensación de los efectos intangibles del daño. 
Por su parte, las condenas dinerarias por gastos inexistentes configurarían la compensación de daños carentes de prueba. Desde luego que la condena a reparar en naturaleza también debe basarse en pruebas. Si lo reparable es lo que puede restablecerse o restaurarse, o sea el elemento objetivo del daño, entonces la prueba debe recaer sobre ese elemento. Con base en ella, el juez debe ordenar la reparación, imponiendo una obligación de hacer, de no hacer o de dar una cosa que no sea dinero.

Ahí cabría, de nuevo, el ejemplo del vehículo: a título de reparación en naturaleza, el juez podría condenar al ladrón a dar ${ }^{66}$ o entregar un vehículo de las mismas características del que fue robado, pero no a darle a la víctima el dinero para comprarlo. Lo mismo podría decirse del tratamiento médico: la condena podría consistir en proveer directamente los medicamentos, las prótesis, la silla de ruedas, etc., pero no en darle a la víctima el dinero para adquirirlos.

En los dos ejemplos anteriores podría pensarse que confundimos el daño incierto con el daño futuro, pero no hay tal confusión. En el caso del carro robado, hay un daño emergente presente o consolidado, pues su dueño ya padeció la pérdida ${ }^{67}$ : su patrimonio ya se aminoró por el egreso del bien ${ }^{68}$. En consecuencia, si se condenara al ladrón a pagarle a la víctima el precio del carro, dicho precio constituiría una indemnización, desde luego pecuniaria, del daño emergente consolidado, y no su reparación en naturaleza.

En el caso del dinero para comprar los medicamentos, si se condenara al demandado a pagarlo, se estaría ordenando la indemnización del daño emergente futuro, pues en tiempo presente se tendría la certeza de que en el futuro el demandante necesitaría consumir los medicamentos. De manera que, en este caso, tampoco habría reparación en naturaleza.

Finalmente, tal como la reparación solo es aplicable al elemento objetivo del daño, la indemnización solo es aplicable al elemento subjetivo. Ello se debe a dos razones: en primer lugar, a que las indemnizaciones son prestaciones dinerarias. Así lo reconoce el Diccionario de la lengua española ${ }^{69}$, y así lo entiende buena parte

En el entendido técnico del término dar, o sea transferir o constituir un derecho real. Sobre el concepto de obligación de dar, Fernando Hinestrosa, Tratado de las obligaciones, t. I (Bogotá: Universidad Externado de Colombia, 2007), 122; Jorge Cubides, Obligaciones (Bogotá: Pontificia Universidad Javeriana y Grupo Editorial Ibáñez, 2018), 50; Guillermo Ospina Fernández, Régimen general de las obligaciones (Bogotá: Temis, 2005), 25.

Código Civil colombiano, art. 1613: "Entiéndase por daño emergente el perjuicio o la pérdida...".

"El daño emergente es la disminución que sufre el patrimonio [...] en forma de pérdida, deterioro, menoscabo o extinción de bienes valorables pecuniariamente...". Jorge Santos Ballesteros, Responsabilidad civil, t. I (Bogotá: Pontificia Universidad Javeriana y Temis, 2012), 347. definición legal en otro sentido. 
de la doctrina ${ }^{70}$. En segundo lugar, la naturaleza dineraria de la indemnización la incapacita para restaurar el statu quo ante. El profesor Cadiet lo explicó certeramente: la indemnización "es una solución por defecto; una compensación que tranquiliza las penas sin erradicar los males"11.

Por consiguiente, dado que la indemnización supone prestación dineraria, y dada la impotencia del dinero para restaurar de base una situación lesiva ${ }^{72}$, se impone la conclusión de que la indemnización apunta solo a compensar, obrando como un lenitivo que procura el alivio sin curar la enfermedad ${ }^{73}$. De ahí que los efectos nocivos de la lesión al derecho o interés solo puedan compensarse, y solo mediante el pago de una indemnización.

En consecuencia, las categorías de daño emergente, lucro cesante y todas las variedades de los daños extrapatrimoniales conforman el ámbito operacional de las indemnizaciones, mientras que las categorías de los derechos subjetivos y de los intereses lícitos conforman el ámbito operativo de la reparación, que, en cuanto tal, solo puede ser en naturaleza.

Lo dicho hasta aquí nos permite concluir que el objeto reparable es el elemento objetivo del daño, y que su elemento subjetivo es compensable por medio de una indemnización. $Y$, como el objeto de la responsabilidad es la reparación integral del daño, dicha integralidad supone la sumatoria de la reparación del elemento objetivo y de la indemnización plena del elemento subjetivo.

Si no es viable reparar en naturaleza -lo que ocurre, por ejemplo, si el daño consiste en una amputación-, la reparación simplemente no sería integral, en cuyo caso no se habría cumplido el mandato de optimización que entraña cualquier principio ${ }^{74}$.

Así pues, la integralidad supone la conjunción de la reparación, que siempre se hará en naturaleza, y de la indemnización, que siempre se hará en dinero. La falta de alguna de las dos configura la falta de integralidad, a menos que la lesión al

70 Henao, "Las formas de reparación”, 285.

71 Cadiet, “Les métamorphoses du préjudice”, 63.

72 Puesto que el dinero es incapaz de proveer una restitutio in integrum: él no puede borrar la lesión al derecho o interés afectado; tan solo puede conjurarla o mitigarla, pero sin hacerla desaparecer de la realidad fáctica.

73 "La reparación por compensación supone la imposibilidad de restablecer la situación anterior al daño. Ella consiste entonces, más modestamente, en compensar el daño sufrido por la víctima, es decir, en concederle un beneficio que contrabalancee el detrimento irremediable que le ha sido infligido". Fabrice Leduc, "La conception générale de la réparation intégrale", en La réparation intégrale en Europe (Bruselas: Larcier, 2012), 41.

74 Según la Corte Constitucional colombiana, los principios son mandatos de optimización "que ordenan que algo se realice en la mayor medida posible según las posibilidades fácticas y jurídicas" (énfasis añadido). Sentencia C-713 del 15 de julio del 2008. 
derecho no haya desatado consecuencias nocivas. En ese caso la indemnización se inaplica por improcedente, sin menoscabar con ello la integralidad, que se alcanzaría con la reparación, si ella es realizable.

La argumentación presentada nos permite, como colofón de esta primera parte, proponer una noción de reparación en naturaleza: es una forma de resarcimiento que tiene por objeto restablecer el derecho o interés lesionado, por medio de una prestación de hacer, de no hacer o de dar algo que no sea dinero. A continuación, veremos que esa forma de resarcimiento no se compasa con otras figuras, cercanas pero disímiles, con las que se suele confundir la reparación en naturaleza.

\section{Reparación (en naturaleza) y materias aledañas}

La reparación en naturaleza se aproxima a otras figuras. Concretamente, la doctrina la ejemplifica a partir de la ejecución en naturaleza $(A)$, de la cesación del hecho ilícito (B) y de la reparación simbólica (C). Enseguida veremos por qué ninguno de los tres casos configura reparaciones en naturaleza.

\section{A) Reparación en naturaleza y ejecución en naturaleza}

El incumplimiento de obligaciones trae, entre otros efectos, el de reparar los daños que de él se deriven. En la dicotomía de las formas de reparación (reparación en naturaleza vs. reparación pecuniaria) parece lógico pensar que la forma de reparar un daño derivado de la inejecución de una obligación sea ejecutándola. Así lo entendieron, entre otros, los hermanos Mazeaud ${ }^{75}$, Chartier ${ }^{76}$ y Royer d'Elloy ${ }^{77}$.

Sin embargo, esa lógica queda desvirtuada cuando se analiza la obligación reparatoria. Dos criterios permiten analizarla: los denominaremos criterio funcional

75 La reparación en naturaleza se traduce en una condena "que compele al demandado a ejecutar su obligación positiva o a abstenerse de ejecutar el acto contrario a su obligación negativa, o a destruir lo que haya hecho en contravención de esa obligación": Henri, Leon y Jean Mazeaud, Traité théorique et pratique de la responsabilité civile délictuelle et contractuelle, t. III (París: Montchrestien, 1983), 2303.

76 Según este autor, la ejecución "al ponerle fin al daño del acreedor, constituye, al menos hacia el futuro, la más perfecta de las reparaciones": Yves Chartier, La réparation du préjudice dans la responsabilité civile (París: Dalloz, 1983), § 383.

77 “La ejecución parecería ser el paso obligado de la reparación en naturaleza": Claude Royer d'Elloy, La réparation en nature en matiere de responsabilité civile, tesis doctoral (mimeografiada) (Grenoble: Universidad de Grenoble, 1994), 18. 
y criterio causal. Según el funcional, la prestación impuesta al deudor incumplido tendrá naturaleza de ejecución cuando ella consista en efectuar exactamente lo que el deudor prometió ejecutar. En otras palabras, la prestación constituirá ejecución, y no reparación, cuando el dar, el hacer o el no hacer puedan considerarse pago, por concretar "la prestación de lo que se debe" criterio ha sido establecido con los mismos fines por otros autores ${ }^{79}$.

Ahora bien, el criterio funcional podría objetarse acogiendo la tesis de que la responsabilidad contractual no existe. Dicha tesis ha sido expuesta en Francia, en distintos momentos de la historia ${ }^{80}$. La proposición que la sustenta es la siguiente: la indemnización de perjuicios contractuales no tiene por objeto reparar los daños derivados del incumplimiento, sino efectuar un pago subrogado de la obligación incumplida; es decir, un pago "por equivalente".

De esa proposición se siguen varios efectos, según sus autores. En primer lugar, la indemnización es un remedio contractual frente al incumplimiento, y no constituye un mecanismo de responsabilidad como la aquiliana, que sería la única responsabilidad civil. En segundo lugar, el pago "por equivalente" provoca indirectamente la indemnidad del acreedor, respecto de los daños intrínsecos ${ }^{81}$. En tercer lugar, la reparación de los demás daños se alcanzaría por medio de la responsabilidad extracontractual. En cuarto lugar, la indemnización no se debe por haber causado un daño, sino por haber incumplido una obligación ${ }^{82}$.

Esta tesis, por su propio contenido, impide concebir la existencia de la reparación en naturaleza en materia contractual. Para ella, la dicotomía no se concreta

Marie-Eve Roujou de Boubée, Essai sur la notion de ráparation (París: LGDJ, 1974), 146; LouisFrédéric Pignare, Les obligations en nature et de somme d'argent: Essai de théorisation à partir d'une distinction (París: LGDJ, 2010), 474; Paul Grosser, Les remèdes à l'inexécution du contrat: Essai de classification, tesis doctoral (mimeografiada) (París: Universidad París 1, 2000), 373; Julien Coulet, L'exécution forcée en nature, tesis doctoral (mimeografiada) (París: Universidad París 2, 2007), 296.

80 Charles Sainctelette, De la responsabilité et de la garantie (Bruselas: Bruylant-Christophe \& Co. y París, Libraire A. Marescq, 1884); Jean Grandmoulin, De l'unité de la responsabilité ou nature délictuelle de la responsabilité pour violation des obligations contractuelles (París: A. Le Roy, 1892); Philippe Rémy, "La responsabilité contractuelle: histoire d'un faux concept", Revue trimestrielle de droit civil (1997), 323; Philippe Le Tourneau, Droit de la responsabilité et des contrats (París: Dalloz, 2012-2013), 5; de este mismo autor, "De la falsedad del concepto de 'responsabilidad contractual'", Esperanza Meléndez (trad.), Estudios de derecho civil en homenaje a Fernando Hinestrosa (Bogotá: Universidad Externado de Colombia, 2014), passim.

81 O sea, de aquellas pérdidas que resultan directamente del incumplimiento: el precio que no se pagó, la cosa que no se entregó o la prohibición infringida. Por oposición a los daños extrínsecos, que son las pérdidas consiguientes al incumplimiento, como los daños extrapatrimoniales. Esta dicotomía es de la autoría de Robert Pothier: Traité des obligations, t. I (París: Dalloz, 2011 [reimpresión]), 170 y ss.

82 Pues así lo establece la ley cuando dice que el lucro cesante y el año emergente se deben por no haberse cumplido la obligación o por haberse cumplido de forma imperfecta o tardía (art. 1613 del Código Civil colombiano, 1231-1 del Código Civil francés actual y 1147 de la versión original de este último). 
entre reparación en naturaleza y reparación económica, sino entre ejecución en naturaleza y ejecución "por equivalente" ${ }^{83}$.

Esa tesis es inconsistente por varias razones. En primer lugar, el Código Civil francés, tanto en la versión original como en la actual ${ }^{84}$, permiten acumular la resolución con la indemnización. Lo mismo ocurre con el código colombiano ${ }^{85}$. En consecuencia, es ilógico afirmar que la indemnización es un medio de ejecución del contrato, pues la ley autoriza la acumulación de la indemnización con la resolución, y sabemos que esta última se dirige a romper el contrato. Por ende, si en un caso concreto el acreedor acumula en juicio la resolución y la indemnización, no podría afirmarse que esta constituye una ejecución subrogada del contrato, puesto que el acreedor optó por romperlo 86 .

La tesis, además, es imprecisa desde el punto de vista terminológico. La expresión "ejecución por equivalente" es absurda. Si el pago es "la prestación de lo que se debe" 87 , la única manera de realizarlo es en naturaleza. Lo que se debe no tiene equivalente. "No es posible ejecutar algo por equivalente, so pena de ceder a la contradicción" 88 . Mediante la indemnización, el deudor ejecuta una prestación distinta de la original, y, precisamente por ser distinta, debe descartarse su calificación como ejecución por equivalente ${ }^{89}$.

Una tercera inconsistencia radica en afirmar que la indemnización contractual se reduce a los daños intrínsecos, mientras que los extrínsecos se indemnizan por la vía extracontractual ${ }^{90}$. Esa solución implica someter a la víctima a interponer dos acciones distintas para alcanzar un mismo objetivo, la indemnidad, a pesar de que los dos tipos de daño surgen del mismo hecho: el incumplimiento. Además,

En igual sentido, Geneviève Viney, Introduction à la responsabilité (París: LGDJ, 2008), 451.

En el 2016, el derecho de obligaciones fue reformado por el Decreto-ley 2016-131. Este tipificó los desarrollos jurisprudenciales que en la materia había desarrollado por más de cien años la Corte de Casación.

Código Civil colombiano, art. 1546.

En igual sentido, Geneviève Viney, "La responsabilité contractuelle en question", en Études offertes à Jacques Ghestin (París: LGDJ, 2001), 928.

Código Civil colombiano, art. 1626.

Barry, "La réparation en nature", 139.

Por ello la figura de la dación en pago es igualmente absurda. Ella esconde una novación por cambio de objeto. En igual sentido, Ricardo Uribe-Holguín, De las obligaciones y de los contratos en general (Bogotá: Temis, 1982), 143.

Esa dualidad fue planteada por Pothier. El fragmento en el que mejor lo graficó fue en el del famoso ejemplo de la vaca enferma que contamina a las otras vacas. El daño intrínseco se materializa en la vaca enferma, pues constituye el incumplimiento de la obligación de entregar; el extrínseco se materializa en la afectación a las otras vacas: Pothier, Traité des obligations, 190. 
esa solución desconoce que los términos de prescripción para cada acción son distintos, y que la interposición de dos demandas significa duplicar los costos de la víctima.

En resumen, el criterio que llamamos funcional podría ponerse en entredicho con la tesis de la inexistencia de la responsabilidad contractual. Esta, sin embargo, fue debidamente refutada. Ahora resta explicar el criterio causal, que al lado del funcional sirve para deslindar la ejecución en naturaleza de la reparación en naturaleza.

El criterio causal se sustenta en la disparidad de fuentes de las respectivas obligaciones ${ }^{91}$. La obligación de ejecutar la obligación surge del contrato, mientras que la de reparar surge del daño $0^{92}$. El contrato determina el nacimiento, las modalidades y la exigibilidad de las obligaciones que de él emergen. El daño determina las reglas de su reparación. Si eso es así, la obligación de reparar es posterior a la obligación incumplida y, por ende, distinta.

La posterioridad en el nacimiento de la obligación de reparar repercute en la prescripción. El punto de partida del término prescriptivo difiere para cada una. El de la ejecución depende de la exigibilidad de la obligación incumplida; el de la reparación, de la ocurrencia del daño o de su manifestación. Esa disparidad solo es explicable bajo el entendido de que se trata de obligaciones distintas.

Por otra parte, el Código Civil colombiano permite acumular la ejecución con la indemnización en un mismo proceso ${ }^{93}$. Esa norma fue calcada del artículo 1184 de la versión original del código francés, que establecía la misma posibilidad de acumulación ${ }^{94}$. El Código de Comercio colombiano hace lo propio ${ }^{95}$.

La única manera de entender razonablemente esa acumulación es distinguiendo ejecución de reparación. Es obvio que la acumulación de dos elementos supone su distinción. En el caso bajo análisis, se trataría de dos pretensiones judiciales: una dirigida a ejecutar una deuda insoluta, y la otra, a declarar una responsabilidad.

91 Lo denominamos criterio causal, en el entendido de que las fuentes de las obligaciones son sus causas, tal como lo entendió Pothier en su tratado de las obligaciones: Pothier, Traité des obligations, 16.

92 Fernando Hinestrosa, Tratado de las obligaciones, t. II, v. I (Bogotá: Universidad Externado de Colombia, 2015), 66 y 67.

93 "En los contratos bilaterales va envuelta la condición resolutoria en caso de no cumplirse por uno de los contratantes lo pactado. Pero en tal caso podrá el otro contratante pedir a su arbitrio, o la resolución o el cumplimiento del contrato con indemnización de perjuicios".

94 El artículo 1217 de la versión actual también la establece, diciendo que los remedios contractuales son acumulables.

$95 \quad$ Art. 870. 
Si la ejecución fuera reparación, el permiso para acumularlas sobraría, y eso, en el mejor de los casos, atentaría contra el principio del efecto útil de las normas ${ }^{96}$.

Otro argumento que corrobora la distinción que defendemos se sustenta en la figura de la mora. Para declarar la responsabilidad contractual, se necesita que el deudor esté constituido en mora. Para condenarlo a pagar la obligación incumplida, ello no es necesario. Lo anterior se deduce de dos normas del Código Civil colombiano: por una parte, el artículo 1615 dispone que la reparación se debe "[...] desde que el deudor se ha constituido en mora o, si la obligación es de no hacer, desde el momento de la contravención". Por otra parte, el artículo 1494 ibidem dispone lo siguiente: "Antes de constituirse el deudor en mora, no puede el acreedor demandar a su arbitrio la obligación principal o la pena, sino solo la obligación principal" (énfasis añadido).

Estas dos normas deben interpretarse armónicamente. Ambas comparten dos elementos: el incumplimiento y la regulación de algunos de sus efectos. La primera le atribuye consecuencias al incumplimiento dañoso, y la segunda se las atribuye al incumplimiento simple. Para el dañoso la ley le otorga al acreedor la posibilidad de pedir una indemnización, exigiéndole constitución en mora del deudor. Para el simple, le permite tan solo cobrar la obligación incumplida, sin pedirle la constitución en mora ${ }^{97}$. De nuevo, esa dualidad en el tratamiento conlleva la distinción de las dos obligaciones, la de ejecutar y la de reparar, pues solo puede justificarse la dualidad en el tratamiento, si se acepta la distinción de las dos obligaciones.

Siguiendo con la confrontación entre la reparación en naturaleza y las figuras aledañas, trataremos ahora el tema de los hechos ilícitos potencialmente dañosos y de los hechos de cuya lesividad o inocuidad no se tiene certeza científica. Ambos conforman el género de los mecanismos de tutela preventiva.

\section{B) Reparación en naturaleza y mecanismos de tutela preventiva}

El Código Civil colombiano consagra una acción preventiva. Lo hace en el artículo 2359, bajo la rúbrica del daño contingente que pueda afectar a personas indeterminadas. Esa norma se ubica en la sección dedicada a la responsabilidad

96 " [...] Debe considerarse, de entre varias interpretaciones de una disposición normativa, aquella que permita consecuencias jurídicas sobre la que no las prevea, o sobre la que prevea consecuencias superfluas o innecesarias": Colombia, Corte Constitucional, Sentencia C-569/04, del 8 de junio del 2004.

En palabras de la Corte Suprema de Justicia de Colombia, "El deudor cumple el contrato, antes de constituirse en mora, ejecutando el objeto debido tal como fue pactado...": Sala de Casación Civil, sentencia del 3 de noviembre de 1977, G. J. t. CLV, n. ${ }^{\circ} 2396,324$. 
extracontractual. Por su parte, la Ley 472 de 1998 consagra una acción popular que busca evitar la concreción del daño eventual.

Esos textos llevan a pensar que la prevención del daño es una función de la responsabilidad $^{98}$. Se sabe que esta necesita de un hecho generador y de un daño que pueda ligarse causalmente con ese hecho. Por su parte, las acciones de cesación del hecho ilícito propenden por evitar que un hecho potencialmente generador de daños los genere efectivamente. De tal comunidad de elementos es fácil deducir una relación de género a especie, en la que la cesación del ilícito se erige como forma reparación y, por ende, como forma de responsabilidad ${ }^{99}$.

Así mismo, cada vez que la ciencia tenga dudas sobre la lesividad o la inocuidad de una situación fáctica determinada, debe optarse por descartar el sostenimiento de la situación. Mutatis mutandis, a eso se le denomina principio de precaución ${ }^{100}$. Este es considerado como parte integrante de la responsabilidad, para quienes le adjudican funciones preventivas ${ }^{101}$.

Emparentar los mecanismos de tutela preventiva con la responsabilidad es errado. Esta busca reparar los daños. Aquellos buscan que no los haya. Por ello la responsabilidad necesita la prueba de un daño cierto, mientras que aquellos solo precisan la prueba de un hecho con potencial dañoso. Si el daño ya se ha concretado, la tutela preventiva resulta improcedente. La responsabilidad, en fin, requiere un nexo causal entre el daño y el hecho generador, mientras que la eficacia de la tutela preventiva supone la inocuidad de aquel hecho.

Además, adjudicarle una función profiláctica a la responsabilidad conduce a desvirtuarla. Ella es esencialmente retrospectiva ${ }^{102}$. El juez le imputa al demandado un daño que ya causó, y le atribuye la obligación de resarcirlo. Por tal razón, el daño

98 Promueven una función preventiva de la responsabilidad, entre otros, Cyril Sintez, La sanction préventive en droit de la responsabilité civile (París: Dalloz, 2011), passim; Suzanne Carval, La responsabilité civile dans sa fonction de peine privée (París: LGDJ, 1995), passim; Melvin Munir Cohen-Puerta, La responsabilidad civil como derecho preventivo y resarcitorio de daños (Medellín: Librería Jurídica Sánchez R., 2018), passim.

99 Y esta no podría serlo sino en naturaleza, pues se erradica la fuente generadora del daño.

100 Daphne Tapinos, Prévention, précaution et responsabilité civile (París: L'Harmattan, 2008), 25; Mathilde Boutonnet, Anne Guegan, "Histoire du principe de précaution", en Le principe de précaution. Rapporte au Premier ministre (París: Odile Jacob, 2000), 253.

101 Mathilde Bouttonet, Le príncipe de précaution en droit de la responsabilité civile (París: LGDJ, 2005); Catherine Thibierge, "Libres propos sur l'évolution du droit de la responsabilité civile (vers un élargissement de la fonction de la responsabilité civile?", Revue trimestrielle de droit civil (1999): 561.

102 Según la Corte Suprema de Justicia de Colombia, "las reglas de imputación de responsabilidad civil están dirigidas al juzgador para valorar el hecho del agente ex post facto, a fin de atribuirle una situación jurídica, con independencia de que muchas de ellas cumplan además una función prospectiva para regular la conducta...". Colombia, Sala de Casación Civil, del 12 de enero del 2018, rad. 11001 310302720100057801. 
y la víctima son elementos esenciales de la responsabilidad. En cambio, una hipotética función preventiva conllevaría la posibilidad absurda de una responsabilidad sin daño y sin víctima.

Finalmente, la cesación del hecho ilícito, como lo sugiere su nombre, entraña la ilicitud de una conducta. La responsabilidad, en cambio, puede imputarse en caso de que el hecho generador sea lícito. Piénsese en la responsabilidad derivada de la conducción de automóviles o en la navegación aérea y marítima. Las dos son actividades lícitas y, sin embargo, engendran responsabilidad. Eso prueba que el daño, y no el hecho ilícito, es la fuente de la obligación de reparar, lo que, a su vez, ratifica su esencialidad para la responsabilidad y el carácter remedial de esta última.

Por otra parte, y para finalizar la confrontación entre la reparación en naturaleza y las materias aledañas, abordaremos ahora el análisis de la "reparación" simbólica.

\section{C) Reparación en naturaleza y "reparación” simbólica}

Los procesos de responsabilidad a veces terminan con sentencias condenatorias que imponen prestaciones de hacer ${ }^{103}$, a las que se les atribuye la naturaleza de una "reparación simbólica". Los ejemplos típicos son los de la publicación de la sentencia de condena, la orden de pedirle públicamente perdón al agraviado y la de pagar una suma irrisoria, como un euro simbólico.

En la jurisprudencia colombiana, esas medidas se han sustentado en la necesidad de aplicar el principio de reparación integral ${ }^{104}$. Es decir que, frente a un fallo de condena, esta se considera insuficiente si solo se ordena pagar el valor del daño emergente, el lucro cesante y los daños inmateriales. Para "completarla", entonces, se acude a la imposición de medidas simbólicas. Y, para justificar esa parte de la condena, se acude al lugar común de que esta configura una forma de reparación en naturaleza.

En la doctrina, algunos comparten la idea de que las prestaciones simbólicas son formas de reparación en naturaleza ${ }^{105}$.Otros, en cambio, piensan que tras las

103 Colombia, Corte Suprema de Justicia, Sala de Casación Civil, del 24 de mayo de 1999, exp. 5244; Colombia, Consejo de Estado, Sección Tercera, sentencia del 14 de abril del 2010, exp. 18.960, y del 20 de febrero del 2008, exp. 16.996.

104 Colombia, Consejo de Estado, Sección Tercera, sentencia del 14 de abril del 2010, exp.18.960, y del 20 de febrero del 2008, exp. 16.996.

105 Jacques Flour, Jean-Luc Aubert, Eric Savaux, Droit Civil. Les obligations, t. 2, Le fait juridique (París: Sirey, 2011), 499; Viney, Jourdain, Carval, “Les effets”, § 33. 
condenas simbólicas subyace una pena privada ${ }^{106}$. Esta última constituye una medida punitiva que pretende sancionar a quien ha cometido una conducta dolosa o culposa. Su objetivo es penalizarla y disuadirla de reincidir, al tiempo que ejemplariza al resto de la sociedad para que se abstenga de imitar al infractor condenado. Su leitmotiv no es la víctima ni su reparación integral, sino el victimario y la necesidad de penalizarlo para que no reincida.

Compartimos la tesis de que la "reparación" simbólica constituye una pena privada. En efecto, para imponerla no se tienen en cuenta criterios rigurosos de reparación. Más bien se tiene en cuenta la conducta del responsable, en especial su gravedad, puesto que la finalidad de la condena no es la indemnidad de la víctima, sino la sanción ejemplarizante y moralizadora del victimario.

Por otra parte, si se entiende el principio de reparación integral como la reparación de "todo el daño, pero nada más que el daño"107, no puede entenderse al mismo tiempo que la prestación simbólica sea una manera de aplicarlo, pues para la fijación de tal prestación se prescinde de la magnitud efectiva del daño y de las tipologías que este pueda revestir en un caso sub iudice.

Es evidente que publicar una sentencia o pedir perdón son prestaciones que no concuerdan cuantitativa ni cualitativamente con el concepto de reparación. Piénsese, por ejemplo, en el lucro cesante: ¿podría afirmarse razonablemente que este queda reparado con una petición de perdón o con la publicación de una sentencia? No lo creemos. Apelando exclusivamente a la noción técnica de reparación integral ${ }^{108}$, ello es imposible.

Otra cosa, y muy distinta, es que la víctima sienta algún alivio personal por el cumplimiento de esas prestaciones. Para ella pueden resultar satisfactorias en términos emocionales, pero eso no las transforma en herramientas idóneas para resarcir, al menos bajo el entendido técnico-jurídico de la reparación integral.

Finalmente, las prestaciones simbólicas solo son procedentes en los regímenes de responsabilidad subjetiva ${ }^{109}$. Es natural que, si tales prestaciones propugnan

106 En el sistema anglosajón esta figura se denomina punitive damage, que, por defectos de traducción, en el mundo hispano se ha denominado daño punitivo, cuando lo punitivo no es el daño sino la indemnización, verdadero significado, en inglés jurídico, de la palabra damages.

107 Arnaud Le Jollec, Dommage corporel: le sacro-saint principe de réparation intégrale. https://www. village-justice.com/articles/Dommage-corporel-Sacro-Saint-principe-reparation-integrale,25458.html

108 La víctima podría quedar satisfecha e incluso sentirse reparada con la petición de perdón o la publicación de la sentencia. Eso es indiscutible. Pero esa concepción subjetiva no corresponde al concepto técnico de reparación. En otros términos: que la víctima se sienta reparada no significa que jurídicamente lo esté.

109 Ph. Brun, "Les peines privées en droit français", L'indemnisation, Travaux de l'Association Henri Capitant, Journées québécoises, t. LIV, 2004, 155. En Francia, este tipo de condenas se han impuesto 
la sanción y disuasión del responsable, ellas solo sean viables cuando su responsabilidad se derive de conductas culposas o dolosas. En caso contrario, se lo sancionaría por ejercer actividades lícitas e irreprochables, lo que repugna a la lógica sancionatoria ${ }^{110}$.

Contrario sensu, la reparación en naturaleza es procedente en los sistemas objetivos y subjetivos de responsabilidad. Esa forma de reparación, en cuanto recurso de la responsabilidad, no se impone para castigar conductas ilícitas, ni para ejemplarizar, ni para disuadir; mucho menos para moralizar. La responsabilidad se centra en la reparación plena de los daños, y con ella alcanza su objetivo: la indemnidad de la víctima.

\section{Conclusiones}

Esta investigación nos permitió concluir que la dicotomía entre reparación en naturaleza y reparación dineraria es artificiosa. La reparación solo es viable si se hace en naturaleza. El dinero no tiene la aptitud de reparar, si hacerlo implica restablecer el derecho vulnerado. Por lo tanto, en la tipología universal de los daños patrimoniales, lucro cesante y daño emergente, su reparación es irrealizable. Esos daños, por su estructura, solo pueden ser compensados con sumas de dinero. Lo mismo ocurre con los daños inmateriales.

También concluimos que la integralidad del resarcimiento supone la reparación de lo reparable y la compensación de lo compensable. Lo reparable es la lesión al derecho o al interés, o sea el elemento objetivo del daño; lo compensable es el elemento subjetivo. La imposibilidad de reparar y compensar, que se verifique en un caso concreto, ratifica que la reparación integral es un principio, entendido como mandato de optimización ${ }^{111}$.

Por otra parte, concluimos que los medios de tutela preventiva, la ejecución coactiva de obligaciones y las medidas de reparación simbólica no constituyen

en casos de daños al honor, a la reputación y a la vida privada, lo que denota el carácter esencialmente culposo de la atribución de responsabilidad: en igual sentido, Barry, "La réparation", 314 y 315.

110 "A menos que pudiera sustentarse la idea improbable de que la posibilidad de que se declare la responsabilidad extracontractual llega a desestimular conductas legítimas y, por lo general, útiles para la sociedad, lo que, en todo caso, no parece un fin deseable": M'Causland, "Equidad judicial", 346.

111 En sentido contrario, Solarte Rodríguez opina que la reparación integral tiene tantas excepciones que carece de la estabilidad que entraña cualquier principio: Solarte, "Principio de la reparación", 121-155. 
formas de reparación en naturaleza. Esto se debe a que en algunos casos esas figuras exigen cosas que la reparación no exige o prescinden de cosas que la reparación requiere.

Finalmente, el objetivo de elaborar una noción de reparación en naturaleza se cumplió adecuadamente. La dejamos, pues, al escrutinio de la crítica: la reparación en naturaleza es una forma de resarcimiento que tiene por objeto restablecer el derecho o interés lesionado, por medio de una prestación de hacer, de no hacer o de dar algo que no sea dinero.

\section{Referencias}

Barry, Brunehilde. La réparation en nature. París: LGDJ y Presses de l'Université Toulouse 1 Capitole, 2016.

Boutonnet, Mathilde y Anne Guegan. "Histoire du principe de précaution". En Le principe de précaution. Rapporte au Premier ministr. París: Odile Jacob, 2000.

Bouttonet, Mathilde. Le principe de précaution en droit de la responsabilité civile. París: LGDJ, 2005.

Brun, Philippe. Responsabilité civile extracontractuelle. París: Lexis Nexis, 2014.

—. "Personnes et préjudice". Revue Générale de Droit (2003).

Cadiet, Loïc. "Les métamorphoses du préjudice". En Les métamorphoses de la responsabilité. París, PUF, 1998.

-. Le préjudice d'agrément, tesis doctoral (mimeografiada). Poitiers: Universidad de Poitiers, 1983.

Carval, Suzanne. La responsabilité civile dans sa fonction de peine privée. París: LGDJ, 1995.

Chartier, Yves. La réparation du préjudice dans la responsabilité civile. París: Dalloz, 1983.

Cohen-Puerta, Melvin Munir. La responsabilidad civil como derecho preventivo y resarcitorio de daños. Medellín: Librería Jurídica Sánchez R., 2018.

Colombia, Corte Constitucional. Sentencia C-569/04, del 8 de junio del 2004. 
-. Sentencia C-713/08 del 15 de julio del 2008.

Colombia, Corte Suprema de Justicia de Colombia, Sala de Casación Civil, sentencia del 3 de noviembre de 1977, G. J. t. CLV, n. 2396.

-. Sentencia del 24 de mayo de 1999, exp. 5244.

—. Sentencia del 12 de enero del 2018, rad. 11001310302720100057801.

-. 5 de agosto del 2014, rad. 11001310300320030066001.

-. sentencia del 3 de abril del 2019, rad. 11001-31-03-015-2010-00268-

01, exp. SC-3653-2019.

- sentencia del 7 de mayo del 2018, rad. 63001-23-31-000-200300463-01 (exp. 33948).

-. Sección Tercera, sentencias del 14 de abril del 2010, exp.18.960, y del 20 de febrero del 2008, exp.16.996.

-. Sección Tercera, sentencias del 14 de abril del 2010, exp.18.960, y del 20 de febrero del 2008, exp.16.996.

Correa-Flórez, María Camila. "Taxonomía de las falacias argumentativas". En Una mirada a la argumentación jurídica, Renata Amaya y Nicolás Parra (coords.). Bogotá: Ediciones Uniandes, 2019.

Coulet, Julien. L'exécution forcée en nature, tesis doctoral (mimeografiada) París: Universidad París 2, 2007.

Cubides, Jorge. Obligaciones. Bogotá: Pontificia Universidad Javeriana y Grupo Editorial Ibáñez, 2019.

Fabre-Magnan, Muriel. Droit des obligations, t. II. París: Presses Universitaires de France, 2013.

Fages, Bertrand. Droit des obligations. París: LGDJ, 2018.

Fischer, Hans. Los daños civiles y su reparación. Madrid: Biblioteca de la Revista de Derecho Privado, 1928.

Flour, Jacques, Jean-Luc Aubert y Eric Savaux. Droit Civil. Les obligations, t. 2, Le fait juridique. París: Sirey, 2011.

Francia, Sentencia del 28 de octubre de 1954, de la Cámara Civil de la Corte de Casación francesa. Juris classeur periodique, 1955, II, 8765.

Gaudemet, Eugène. Théorie générale des obligations. París: Dalloz, reimpresión de la primera edición, 2004.

García, Diego. La oficialización de la pena privada en Colombia. Bogotá: Universidad Externado de Colombia, 2018. 
Giraldo, Óscar. "Los calificativos del derecho en las formas de investigación jurídica”. En O. Agudelo-Giraldo (editor), La pregunta por el método: derecho y metodología de la investigación. Bogotá: Universidad Católica de Colombia, 2018.

Grandmoulin, Jean. De l'unité de la responsabilité ou nature délictuelle de la responsabilité pour violation des obligations contractuelles. París: A. Le Roy, 1892.

Grosser, Paul. Les remedes à l'inexécution du contrat: Essai de classification (tesis doctoral. mimeografiada). París: Universidad de París 1, 2000.

Groutel, Hubert. "Droit francais". En La réparation intégrale en Europe. Bruselas: Larcier, 2012.

Henao, Juan Carlos. "Las formas de reparación en la responsabilidad del Estado: hacia su unificación sustancial en todas las acciones contra el Estado". Revista de Derecho Privado, n. ${ }^{\circ} 18$ (2015).

Josserand, Louis. De l'esprit des droits et de leur relativité. Théorie dit de l'abus des droits. París: reimpresión de la primera edición, Dalloz, 2006.

Leduc, Fabrice. "Faut-il distinguer le dommage et le préjudice?: point de vue privatiste". Revue de Responsabilité Civile et Assurances (marzo del 2010): 16.

-. "La conception générale de la réparation intégrale". En La réparation intégrale en Europe. Bruselas: Larcier, 2012.

Le Jollec, Arnaud. Dommage corporel: le sacro-saint principe de réparation intégrale. https://www.village-justice.com/articles/Dommage-corporelSacro-Saint-principe-reparation-integrale,25458.html

Le Tourneau, Philippe. "De la falsedad del concepto de 'responsabilidad contractual'”. . En Esperanza Meléndez (trad.), Estudios de derecho civil en homenaje a Fernando Hinestrosa. Bogotá: Universidad Externado de Colombia, 2014.

-. Droit de la responsabilité et des contrats. París, Dalloz, 2012-2013.

—. La responsabilité civile. París: Presses Universitaires de France, 2003.

M'Causland, María Cecilia. Equidad judicial y responsabilidad extracontractual. Bogotá: Universidad Externado de Colombia, 2019.

- Tipología y reparación del daño inmaterial en Colombia. Bogotá: Universidad Externado de Colombia, 2015.

Mazeaud, Henri, Jean Mazeaud y Leon Mazeaud. Traité théorique et pratique de la responsabilité civile délictuelle et contractuelle, t. III. París: Montchrestien, 1983. 
Mendoza Ramírez, Álvaro. Obligaciones. Bogotá: Temis, 2020.

Hinestrosa, Fernando. Tratado de las obligaciones, t. I. Bogotá: Universidad Externado de Colombia, 2007.

-. Tratado de las obligaciones, t. II, v. I. Bogotá: Universidad Externado de Colombia, 2015.

Ospina Fernández, Guillermo. Régimen general de las obligaciones. Bogotá: Temis, 2005.

Pignare, Louis. Les obligations en nature et de somme d'argent: Essai de théorisation à partir d'une distinction. París: LGDJ, 2010.

Pinna, Andrea. La mesure du préjudice contractuel. París: LGDJ, 2007.

Pothier, Robert. Traité des obligations, t. I. París: Dalloz, 2011.

Rémy, Philippe. "La responsabilité contractuelle: histoire d'un faux concept”. Revue trimestrielle de droit civil (1997): 323.

Roujou de Boubée, Marie-Eve. Essai sur la notion de réparation. París: LGDJ, 1974.

Royer d'Elloy, Claude. La réparation en nature en matière de responsabilité civile, tesis doctoral (mimeografiada). Grenoble: Universidad de Grenoble, 1994.

Sabard, Olivia. "La forme de la réparation". En La réparation intégrale en Europe. Bruselas: Larcier, 2012.

Sainctelette, Charles. De la responsabilité et de la garantie. Bruselas: Bruylant-Christophe \& Co. y París: Libraire A. Marescq, 1884.

Sánchez Zorrilla, M. "La metodología de la investigación jurídica: características peculiares y pautas generales para investigar en derecho". Revista Telemática de Filosofía del Derecho n. ${ }^{\circ} 14$ (2011). http://www.rtfd.es/ numero14/11-14.pdf

Solarte Rodríguez, Arturo. “La reparación in natura del daño"Revista Universitas, v. 54, n.․ 109, 2005.

-. "Principio de la reparación integral del daño en el derecho contemporáneo". En La responsabilidad civil en el siglo XXI. Medellín: Biblioteca Jurídica Diké y Pontificia Universidad Javeriana, 2009.

Sintez, Cyril. La sanction préventive en droit de la responsabilité civile. París: Dalloz, 2011.

Tapinos, Daphne, Prévention, précaution et responsabilité civile. París: L'Harmattan, 2008. 
Tamayo-Jaramillo, Javier. Tratado de responsabilidad civil, t. II. Bogotá: Legis, 2007.

Thibierge, Catherine, "Libres propos sur l'évolution du droit de la responsabilité civile. vers un élargissement de la fonction de la responsabilité civile ?". Revue Trimestrielle de Droit Civil (1999).

Uribe-Holguín, Ricardo. De las obligaciones y de los contratos en general. Bogotá: Temis, 1982.

Velásquez-Posada, Obdulio. Responsabilidad civil extracontractual. Bogotá: Temis, 2013.

Villabella-Armengol, Carlos, Los métodos en la investigación jurídica. https: //archivos.juridicas.unam.mx/www/bjv/libros/8/3983/46.pdf

Viney, Geneviève. Introduction à la responsabilité. París: LGDJ, 2008.

—. "La responsabilité contractuelle en question". Études offertes à Jacques Ghestin. París: LGDJ, 2001.

Viney, Geneviève, Patrice Jourdain y Suzanne Carval. Traité de droit civil. Les effets de la responsabilité. París: LGDJ, 2011.

Viney, Geneviève, Patrice Jourdain y Suzanne Carval. Les conditions de la responsabilité civile. París: LGDJ, 2013.

Weston, Antony. Las claves de la argumentación, Jorge Malem-Seña (trad.). Bogotá: Editorial Ariel, 2005.

Yzquierdo-Tolsada, Mariano. Responsabilidad civil extracontractual. Madrid: Dykinson, 2019.

Zapata-García, Pedro. Fundamentos y límites de la responsabilidad del Estado. Bogotá: Universidad Externado de Colombia, 2019. 